[Agr. Biol. Chem., Vol. 29, No. 1, p. 80 81, 1965]

\title{
The X-ray Diffraction Pattern of Spores of Bacillus subtilis
}

Sir:

In the course of our study on the structural changes occurring in bacterial endospores during germination " we have recently found that the X-ray diffraction patterns of spores were significantly different from those of vegetative cells. These findings suggest that it may be possible to obtain further informations on the cellular structures specific to bacterial spores by means of X-ray diffractometry.

The present paper describes in outline an experiment concerning the comparison of the X-ray diffraction patterns of spores and of vegetative cells of Bacillus subtilis, and presents some speculations on the possible molecular features of the specific structure newly detected in the spores by X-ray diffractometry.

The Marburg strain of Bacillus subtilis used in this work was grown, by use of Marubishi MRT-2 type jar fermenter, at $37^{\circ} \mathrm{C}$ in the medium which was prepared to contain the following amounts per liter: L-glutamic acid, $2.205 \mathrm{~g}$; L-asparagine (monohydrate), $2.250 \mathrm{~g}$; Ca-pantothenate, $20 \mathrm{mg} ; \mathrm{K}_{2} \mathrm{HPO}_{4}, 3 \mathrm{~g} ; \mathrm{KH}_{2} \mathrm{PO}_{4}$, $1 \mathrm{~g} ; \mathrm{NH}_{4} \mathrm{Cl}, 500 \mathrm{mg} ; \mathrm{NH}_{4} \mathrm{NO}_{3}, 100 \mathrm{mg} ; \mathrm{Na}_{2} \mathrm{SO}_{4}$, $100 \mathrm{mg} ; \mathrm{MgSO}_{4} \cdot 7 \mathrm{H}_{2} \mathrm{O}, 10 \mathrm{mg} ; \mathrm{MnSO}_{4} \cdot 4 \mathrm{H}_{2} \mathrm{O}$, $1 \mathrm{mg} ; \mathrm{FeSO}_{4} \cdot 7 \mathrm{H}_{2} \mathrm{O}, 1 \mathrm{mg} ; \mathrm{CaCl}_{2}, 0.5 \mathrm{mg} ; \mathrm{pH}$ adjusted to 7.2 . $^{\prime \prime}$

The spores and vegetative cells (filamentous stage) grown in the medium were harvested by centrifugation after 90 and 18 hours' in-

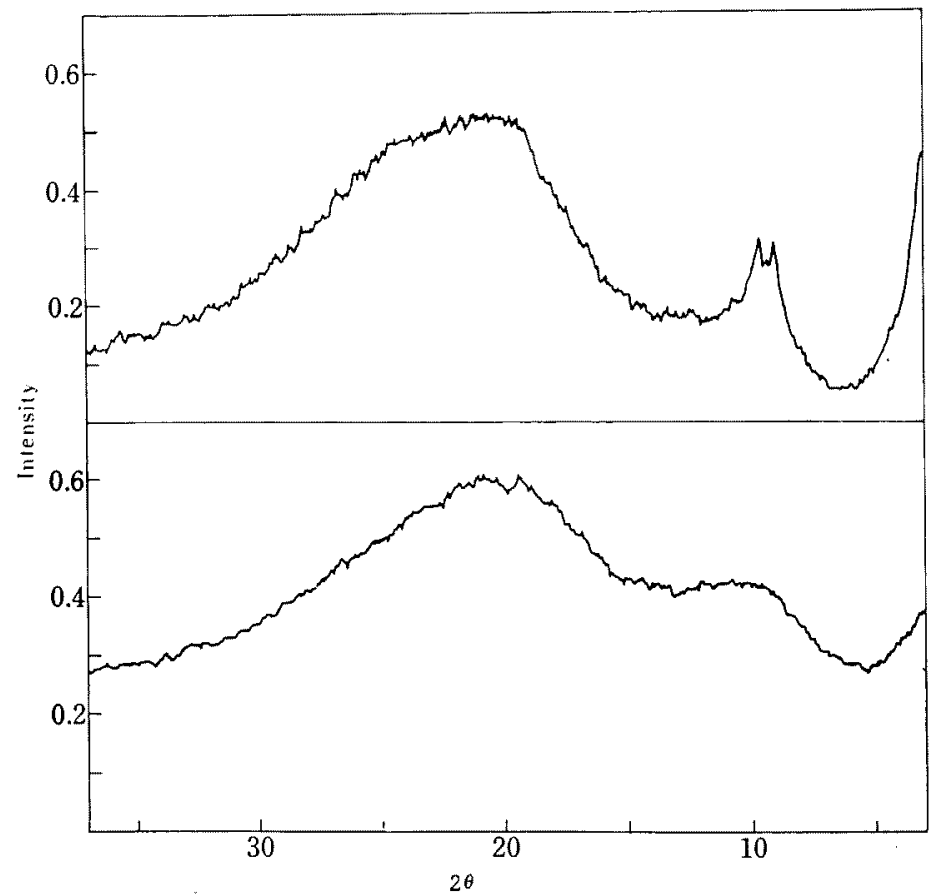

FIG. 1. X-ray diffraction patterns of spores (top) and vegetative cells (bottom) of Bacillus subtilis in dry state.

1) H. Kadota, K. Iijima and Y. Shichi, unpublished work. 
cubation respectively, and then washed extensively with water. The spore suspension was further purified by use of the two-phase "Y" system." The cleaned preparations of spores and vegetative cells thus obtained were lyophilized and stored in a desiccator.

The X-ray diffraction patterns of these dry preparations of spores and vegetative cells were obtained by using a Shimadzu GX-2B $\mathrm{X}$-ray diffractometer, and are illustrated in Fig. 1.

In these X-ray diffraction patterns the vegetative cells showed a broad peak in the region of $20^{\circ}(2 \theta)$ and a broad flat shoulder at $10^{\circ}$, whereas the spores showed two sharp peaks at $9^{\circ}$ and $9.6^{\circ}$, besides a broad one at $20^{\circ}$ The most noticeable difference between the patterns of vegetative cells and spores was the presence of the two sharp peaks (at $9^{\circ}$ and $9.6^{\circ}$ ) in the latter.

It was separately observed by $u s^{1)}$ that the broad flat shoulder at $10^{\circ}$ in the pattern of vegetative cells disappeared with the addition of water to the cell preparation, but the two sharp peaks near $10^{\circ}$ in the spore pattern did not change by such a treatment. The sharp peaks found in the spore pattern, therefore, were thought to be substantially different from the broad shoulder in the pattern of vegetative cells.

The sharp peak at $9^{\circ}$ in the spore pattern indicated that certain periodic (crystalline) structures, of which the lattice distance was calculated to be $9.8 \AA$, were possibly present in the spores. The range of regular arrangement in these periodic structures was found to be above $100 \AA$ by rough estimation. These values obtained with the spore structures were approximately equal to those of keratin. ${ }^{31}$

\footnotetext{
2) L. E. Sacks and G. Alderton, f. Bacteriol., 82, 331 -341 (1961).
}

These facts led us to speculate that keratin-like structures were specifically present in the spores.

In 1959 Vinter $^{4)}$ reported that the content of cystine in free spores of Bacillus was four to five times higher than that of vegetative cells. He suggested later ${ }^{5 /}$ that the cystinerich structure was associated with the spore coats or spore wall rather than the cytoplasm in the spore. According to his data, ${ }^{6)}$ the fraction of insoluble spore wall and coats in Bacillus cereus contained approximately $41 \mu \mathrm{g}$ cystine sulphur per $\mathrm{mg} 1 \mathrm{~N}$ of hydrolyzed trichloroacetic precipitate. These observations may support our speculations as described above. Although direct evidence for the localization of the keratin-like structures in spores is still lacking, it seems likely that these structures are associated with the spore coats which will be discarded during germination. The presence of keratin-like structures may be expected to contribute to the resistance of bacterial spores.

The significance of the other peaks detected in the X-ray diffraction patterns will be reported elsewhere.

We are indebted to Dr. Y. Morita and Mr. Y. Hiiragi of our university for their helpful suggestions during this work. This study was supported by research grants from the Ministry of Education.

\section{Hajime Kadota Koichi IIJIMA}

Laboratory of Microbiology, Research Institute for Food Science,

Kyoto University, Kyoto, Japan.

Received October 5, 1964

3) W. T. Astbury and A. Street, Phil. Trans., A, 230, 75 101 (1932).

4) V. Vinter, Nature, 183, 998 999 (1959).

5) V. Vinter, "Spores" edited by H. O. Halvorson, Burgess Pub. Co., Minneapolis, Minn., 1961, p. 127 141.

6) V. Vinter, Folia Microbiologica, 5, 217 230 (1960), 